\title{
Malnutrition among Indian children
}

\author{
Cyril J Kanmony* \\ Department of Economics, PG \& Research Centre, Scott Christian College, India
}

\section{Introduction}

To have a sustainable and steady economic development in an economy it is a prerequisite that its children should be healthy, educated and trained. Many children in India are illiterates and unskilled and the problem of malnutrition is rampant. It is still having the largest number of malnourished children in the world [1]. In absolute number, it is 26 million [2]. On the basis of data available in 2015, the rate of stunting was $38.7 \%$ and wasting $15.1 \%$. The overall rank of India in the Global Hunger Index (GHI) 2015 was 93 with a score of 31.1 [3]. It is also reported that in India, the per capita disease burden due to child and maternal malnutrition is 12 times higher than that is in China [4]. Even in 2019, the rate of stunting stands at $37.9 \%$ and wasted is close to $21 \%$. India's rank in the Global Hunger Index 2019 is 102 out of 117 countries taken for comparison with a score of 30.3. It is sad to note that even Sri Lanka (66), Nepal (73), Bangladesh (88) and Pakistan (94) are in better positions in nutrition standard than India [5-7]. While the rate of stunting decreased from $42 \%$ in 2010 to $37.9 \%$ in $2019,(54.2 \%$ in 2000) the rate of wasting increased from $17.1 \%$ in 1998- 2002 [7] to almost 21\% in 2019 (GHI 2019). Every year India adds seven million potentially wasted and stunted children to its population.

Malnutrition becomes the cause for the death of many infants and children. Death rates due to severe acute malnutrition range between 2.7\% and 5.2\% among children older than six months (Sachdev 2019 in Chandra 2019). In India, every year about 1.3 million under-five children die [3]. However, the child mortality rate has come down from $9.2 \%$ in 2000 to $4.3 \%$ in 2018 [7]. The infant mortality rate at the national level is 40 deaths per 1,000 live births (146 deaths in 1951). In some States like Odisha it is very much high, 51 deaths per 1,000 live births. It is very low among the high caste people but very high among Schedule Caste people. In Odisha, the IMR for SC people is as much as 78.7 deaths per 1,000 live births (Data Point, The Hindu 06.08.2016). The other factors that aggravate malnutrition among Indian children are lack of sanitation and safe drinking water, low access to healthcare facilities and non-availability of nutritious food. Here the real statuses of these four aspects have been highlighted.

\section{Sanitation}

The most important intervention to achieve the target of cent per cent malnutrition-free India is sanitation. Open defecation is very harmful to all human beings, particularly children. As for as sanitation is concerned, though Swatch Bharat Mission (SBM) was started on the $2^{\text {nd }}$ of October 2014, with the target of $100 \%$ sanitation before the $150^{\text {th }}$ birth anniversary of Mahatma Gandhi, the 2nd of October 2019, India is not still open defecation-free. Due to all the efforts taken by various governments under different schemes the percentage of household toilet coverage increased from $37 \%$ in 2012 to $83 \%$ in 2017-' 18 [8]. As per the Ministry of Drinking Water and Sanitation nearly $95 \%$ of rural households have toilets as on October 2018. In absolute term, under the SBM, 87.5 million household toilets have been constructed so far and only eight million households have to be provided with toilets [9]. But nobody worries about their usage and in many areas, toilets are not used or non-usable due to reasons like non-availability of water or technical flaws.

\section{Safe drinking water}

In India, safe drinking water is not available in many poor households (only $44 \%$ of households have tap water). Those who have no safe drinking water make use of polluted or contaminated water. In India, $90 \%$ of surface water sources is lost due to pollution and encroachment and in most of 640 districts the ground water is highly contaminated, for example, 387 districts are affected by nitrate [9]. Water pollution is the cause for nearly $80 \%$ of all the diseases affecting Indians in one way or the other [10]. The diseases that are caused by faeco-orally transmitted enteric pathogens alone account for $10 \%$ of the total burden of diseases. Among the affected the most affected are children. In India, 1.5 million child fatalities are due to diarrhoea alone, which is solely due to consumption of polluted water. In slum areas of major cities, diarrhoeal incidence is as high as 10.5 episodes per child per year [11].

\section{Healthcare facilities}

In India, the number of qualified health workers available is much less in comparison with developed countries even if both private and public sectors and Allopathy and AYUSH (Indian) health workers are taken together. The decrease in the number of qualified doctors in the country between 2013 and 2017 is estimated at $60 \%$. Doctor-population ratio in India is $758: 10,00,000$ in 2017 . It is lower than that of even South Africa (818), Sri Lanka (881), Pakistan (978) and Brazil $(1,852)$. The ratio at the global level is 1,857 . There are 5,053 SCs without both male and female health workers. The number of SCs without female health worker/s (ANM) is 8,138 and without male health worker/s is 71,433 . The requirement of specialists including paediatricians in Community Health Centres is 21,452 , but there were only 4,078 in post (Rural Health Statistics (RHS) - 2014-'15). In 2018, there was a shortage of $35 \%$ of $24 \times 7$ PHCs and $26 \%$ of medical officer positions (Data dive, Down to Earth, 2019). The number of required PHCs in India is 29,337. But the PHCs in post are only 25,308 (RHS 2014-'15). The number of PHCs in Uttar Pradesh went down from 3,808 in 2002 to 3,497 in 2015 when its population increased nearly $30 \%$ (Ghosh 2017) [12]. There was a $27.22 \%$ shortage of clinical equipment and

*Correspondence to: Cyril Kanmony J, Department of Economics, PG \& Research Centre, Scott Christian College, Nagercoil 629001, India, Tel: +919943869198; E-mail: cyrilkanmony@ymail.com

Received: November 14, 2019; Accepted: January 20, 2019; Published: January 23, 2019 
$56.33 \%$ of non-clinical equipment in Baba Raghav Das Medical College located in Gorakhpur, where 70 children died in 2017 due to shortage of oxygen, which comes under non-clinical equipment category. Fortynine children died due to these reasons in Farrukhad hospital, both the hospitals are in Uttar Pradesh [13].

\section{Underfed children and per capita food availability}

According to the GH Report 2019, over 90\% of Indian children between six and 23 months don't have the minimum food required. The per capita availability of food is also not increasing but decreasing [14]. Though the grains' production increased to 281 million tonnes in 2018, the net per capita food grains availability has decreased to 177.8 $\mathrm{kg}$ in 2018 from $186.2 \mathrm{~kg}$ in 1991. It is $450 \mathrm{~kg}$ in China, $200 \mathrm{~kg}$ even in Bangladesh and $1,100 \mathrm{~kg}$ in the United States (The Economic Survey 2018). However, the most affected by the non-availability of food is the marginalised and the poor due to lack of access to food. Amartya Sen noted that the non-availability of food is not due to food shortages but by inequitable distribution and inadequate access to food because of various socio-economic reasons. Further, the annual food grains absorption rate in India is much lower than that is in sub-Saharan Africa [15].

India is still not able to achieve many of the Millennium Development Goals, particularly malnutrition, child mortality and sanitation not only within the stipulated period but also even after five years thereafter. It is the duty of the government to make available enough food to eat to all its citizens, particularly the poor and marginalised children. As malnutrition is in all ways is a stumbling block to the development of any economy it has to be eliminated. To attain malnourishment-free India, by all means the government must make available to our children enough facilities for both sanitation and safe drinking water and adequate access to healthcare and nutritious food.

\section{References}

1. Abraham, Thomas (2019) The malaise of malnutrition. The Hindu 9.

2. Reddy, Srinath R (2018) Preventing the next health crisis. The Hindu 8.

3. Bali, Vinita (2016) We Need a Nutrition Mission. The Hindu 12.

4. Varshney, Vibha (2019) Empty Stomachs, Down to Earth 176-179.

5. Chandra, Jagriti (2019): India unlikely to meet 'Poshan Abhiyaan' targets, finds study. The Hindu 7.

6. Data dive (2019): State of Rural Health infrastructure Down to Earth 184-185.

7. Jebaraj, Priscilla (2018) $21 \%$ Indian children are under-weight. The Hindu 9.

8. Sengupta, Susmitha, Rashmi V (2018) Loo and Behold, but Beware. Down to Earth $30-40$.

9. Sengupta, Susmitha (2019) Toilets V Sanitation Down to Earth 38 -41.

10. Kanmony J Cyril (2010) Drinking Water Management, Problems and Prospects, Mittal Publications

11. Srividya PV (2016) Drinking Water, Sipping Poison The Hindu 9.

12. Ghosh, Soumitra (2017) Indicaters that matter. The Hindu 8.

13. Varshney, Vibha (2017) Suffocating tragedy Down to Earth 26-29.

14. Patnaik, Prabhat (2016) Economic Liberalisation and the Working Poor. Economic and Political Weekly 47-51.

15. Rawal, Vikas (2013) Freeing the World from Hunger. The Hindu 9.

Copyright: $@ 2020$ Kanmony CJ. This is an open-access article distributed under the terms of the Creative Commons Attribution License, which permits unrestricted use, distribution, and reproduction in any medium, provided the original author and source are credited. 